\title{
Penggunaan Andrographis paniculata Ness untukMenurunkan Hipertensi pada Wanita Menopause
}

\author{
Nicky Danur Jayanti \\ Nicky_daanty@yahoo.co.id \\ Program Studi D III Kebidanan STIKES Widyagama Husada
}

\begin{abstract}
ABSTRAK
Hipertensi pada menopause telah diakui sebagai silent killer atau penyakit yang dapat menimbulkan kematian tanpa disertai dengan gejala-gejala terlebih dahulu. Mengobati hipertensi dapat dilakukan secara medis maupun tradisional. Masyarakat sekarang ini lebih menggemari obat tradisional, karena merupakan pengobatan alternatif yang baik, biaya murah, tanpa efek samping dan jika tekanan darah sudah normal, dapat dihentikan pemakaiannya.Daun sambiloto didukung oleh kandungan zat andrographolide yang pahit rasanya, alkaloid, dan kalium.Kandungan andrographolide mampu meningkatkan sistem pertahanan tubuh seperti produksi sel darah putih yang menyerang bakteri dan benda asing lainnya.Kalium tinggi pada sambiloto berguna untuk mengeluarkan air dan garam untuk mengatasi hipertensi.

Terdapat 26 responden pada penelitian deskriptif ini.Teknik pengambilan sampel menggunakan teknik total sampling yang mana jumlah sampel adalah keseluruhan dari jumlah populasi yaitu 26 wanita menopause penderita hipertensi yang menggunakan daun sambiloto. Teknik pengumpulan data dalam penelitian ini menggunakan wawancara dan pemeriksaan tekanan darah.

Angka hipertensi pada wanita menopause mengalami penurunan, hipertensi berat dari $46,1 \%$ menjadi $0 \%$, sedangkan hipertensi sedang dari $38,5 \%$ menjadi $11,5 \%$, hipertensi ringan dari $15,4 \%$ menjadi $57,7 \%$ dan tekanan darah normal dari $0 \%$ menjadi $30,8 \%$. Diharapkan petugas kesehatan lainnya memberikan penyuluhan cara penggunaan daun sambiloto yang benar dan disarankan kepada wanita menopause untuk menjaga pola hidup dan menggunakan obat tradisional dengan benar.

Kata kunci: Daun Sambiloto, Hipertensi, Wanita Menopause, Obat Tradisional
\end{abstract}




\begin{abstract}
Hypertension aftermenopausehas been recognizedas asilent killer, a disease that cancause deathwithout anysymptoms. Treatinghypertension can bedone medicallyand traditional. People today prefer consuming traditional medicine as the alternative for it is low cost,has no side effects andifthe bloodpressureis normal, people can stop to consume it.Andrographis paniculata Nesscontainsandrographolide, alkaloid, andkalium. The contents ofandrographolidecan improvethe body defensesystemssuch asthe production ofwhite blood cellsthat attack bacteriaandother strange substances. Highkaliumin Andrographis paniculata Nessis usefulto removewaterandsalttotreat hypertension.There were26 respondentsof menopausal womenwithhypertensionwho useAndrographis paniculata Ness in this descriptive research.The data were collectedthroughinterviewsandblood pressure checks. The results showed that after consumingAndrographis paniculata Ness, the percentage of hypertension in postmenopausal women has decreased: severe hypertension decreased from $46.1 \%$ to $0 \%$, the moderate hypertension decreased from $38.5 \%$ to $11.5 \%$, mild hypertensiondecreased from $15.4 \%$ to $57.7 \%$ and normal blood pressure increased from $0 \%$ to $30.8 \%$.It is expected that midwives and other health workers provide counseling on how to use Andrographis paniculata Ness correctly and menopausal women keep their lifestyle healthy and use traditional medicine correctly.
\end{abstract}

Keywords :Andrographis paniculata Ness, Hypertension, Menopausal Women, Traditional Medicine

\section{PENDAHULUAN}

Masa menopause dimulai sejak usia 45 sampai 55 tahun. Pada masa ini, wanita pada umumnya sensitive dengan perubahan tubuhnya baik fisik maupun psikis.Salah satu masalah yang menyertai menopause adalah hipertensi. Hipertensi merupakan masalah kesehatan masyarakat yang disebabkan banyak faktor dan memerlukan penanganan secara baik mengingat prevalensinya yang cukup tinggi. Kenaikan prevalensi hipertensi sejalan dengan bertambahnya usia dan dipengaruhi oleh jenis kelamin seseorang. Saat usia lanjut (lansia) prevalensi hipertensi pada wanita lebih tinggi daripada pria, terlebih saat masa menopause.(Dwi Lestary, 2010)

Prevalensi hipertensi di seluruh dunia, diperkirakan sekitar 15-20\%. Hipertensi lebih banyak menyerang pada usia setengah baya pada golongan umur 55-64 tahun (dimulai saat menopause). Hipertensi di Asia diperkirakan sudah mencapai $8-18 \%$ pada tahun 1997, hipertensi dijumpai pada 4.400 per 10.000 penduduk Asia (Depkes RI 2003).Prevalensi hipertensi di Indonesia mengalami kenaikan dari tahun 1988-1993. Prevalensi hipertensi pada laki-laki dari 134 jiwa (13,6\%) naik menjadi 165 jiwa $(16,5 \%)$, hipertensi pada perempuan dari 174 jiwa (16,0\%) naik menjadi 176 jiwa $(17,6 \%)$ (Setianto Budi,2009). Data WHO tahun 2000 menunjukkan, di seluruh dunia, sekitar 972 juta orang atau 26,4\% penghuni bumi mengidap hipertensi dengan perbandingan $26,6 \%$ pria dan $26,1 \%$ wanita. Dari 972 juta pengidap hipertensi, 333 juta berada di negara maju dan 639 sisanya berada di negara berkembang, termasuk Indonesia (Andra,2007). Hasil Survei Kesehatan Rumah Tangga menunjukkan prevalensi penyakit hipertensi atau tekanan darah tinggi di Indonesia cukup tinggi, yaitu 83 per 1.000 anggota rumah tangga.Hal tersebut terkait erat dengan pola makan, terutama konsumsi garam.(Astawan, 2007). 
Menopause dengan hipertensi merupakan suatu gejala patologi, maka dari itu sangat dibutuhkan perhatian yang lebih. Hipertensi pada menopause telah diakui sebagai silent killer atau penyakit yang dapat menimbulkan kematian tanpa disertai dengan gejala-gejala terlebih dahulu. Hal ini dikarenakan hipertensi merupakan faktor resiko utama pada penyakit stroke, gagal jantung, penyakit arteri koroner dan gagal ginjal.(Mahmud. 2007)

Untuk mengobati hipertensi dapat dilakukan secara medis maupun tradisional. Pengobatan medis dilakukan dengan mengkonsumsi obat-obatan kimia yang dapat menimbulkan beberapa efek samping yang bisa merugikan tubuh klien hipertensi, seperti hipotensi, pusing, sakit kepala, letih, mual, diare, kram otot, nyeri perut, batuk kering, gangguan ginjal (Crawford, 2006). Oleh karena itu, masyarakat sekarang ini lebih menggemari obat tradisional, karena merupakan pengobatan alternatif yang baik, biaya murah, tanpa efek samping dan jika tekanan darah sudah normal, dapat dihentikan pemakaiannya. (Anonim, 2008)

Penurunan hipertensi dengan cara tradisional, salah satunya daun sambiloto. Daun sambiloto didukung oleh kandungan zat andrographolide yang pahit rasanya, alkaloid, dan kalium.Kandungan andrographolide mampu meningkatkan sistem pertahanan tubuh seperti produksi sel darah putih yang menyerang bakteri dan benda asing lainnya.Kalium tinggi pada sambiloto berguna untuk mengeluarkan air dan garam untuk mengatasi hipertensi. (Padmiarso, 2009)

\section{METODE PENELITIAN}

Desainpenelitian yang

digunakandalampenelitianiniadalahdeskri ptifyaituuntukmenggambarkanpenggunaa npemberiandaunsambilotountukmenurun kanhipertensipadawanitamenopause.

Populasidalampenelitianiniadalah $\quad 26$ wanita menopause yang menderita hipertensi yang mengkonsumsi daun sambiloto di desa WonoagungTimur, KecamatanTirtoyudo, Kabupaten Malang.

HASIL

\section{Distribusi Frekuensi Tekanan Darah Sebelum Penggunakan Daun Sambiloto}

Tabel 1 Distribusi frekuensi tekanan darah responden sebelum menggunakan daun sambiloto

\begin{tabular}{ccc}
\hline Tekanan darah & Jumlah & Prosentase \\
\hline Hipertensi Ringan & 4 & $15,4 \%$ \\
\hline Hipertensi Sedang & 10 & $38,5 \%$ \\
\hline Hipertensi Berat & 12 & $46,1 \%$ \\
\hline Total & 26 & $100 \%$ \\
\hline
\end{tabular}

Dari tabel diatas menunjukkan bahwa sebagian besar 12 responden $(46,1 \%)$ mengalami Hipertensi berat (180 - 209 $\mathrm{mmHg}$ ).

\section{Distribusi Frekuensi Lama}

\section{Menggunakan Daun Sambiloto}

Tabel 2 Distribusi frekuensi lama menggunakan daun sambiloto oleh responden

\begin{tabular}{ccc}
\hline Lama & Jumlah & Prosentase \\
\hline$<1$ th & 8 & $30,3 \%$ \\
\hline $1-2$ th & 18 & $69,2 \%$ \\
\hline$>2$ th & 0 & $0 \%$ \\
\hline Total & 26 & $100 \%$ \\
\hline
\end{tabular}

Dari tabel diatas menunjukkan bahwa sebagian besar 18 responden $(69,2 \%)$ menggunakan daun sambiloto selama 1-2 tahun.

\section{Distribusi Frekuensi Cara}

Mengkonsumsi Daun Sambiloto

Tabel 3 Distribusi frekuensi cara mengkonsumsi daun sambiloto oleh responden

\begin{tabular}{ccc}
\hline Cara & Jumlah & Prosentase \\
\hline Rebus & 10 & $38,5 \%$ \\
\hline Seduh & 16 & $61,5 \%$ \\
\hline Total & 26 & $100 \%$ \\
\hline
\end{tabular}

Dari tabel diatas menunjukkan bahwa sebagian besar 16 responden (61,5\%) yang menggunakan cara menyeduh daun sambiloto

4. Distribusi Frekuensi Rutinitas Penggunaan Daun Sambiloto 
Tabel 4 Distribusi frekuensi rutinitas responden penggunakan daun sambiloto

\begin{tabular}{ccc}
\hline Frekuensi & Jumlah & Prosentase \\
\hline Rutin & 0 & $0 \%$ \\
\hline Jika sakit & 26 & $100 \%$ \\
\hline Total & 26 & $100 \%$ \\
\hline
\end{tabular}

Dari tabel diatas menunjukkan bahwa keseluruhan wanita menopause menggunakan daun sambiloto jika sakit saja.

5. Distribusi Frekuensi Tekanan Darah Setelah Penggunaan Daun Sambiloto Tabel 5 Distribusi frekuensi tekanan darah responden setelah menggunakan daun sambiloto

\begin{tabular}{ccc}
\hline Kriteria hasil & Jumlah & Prosentase \\
\hline
\end{tabular}

\begin{tabular}{lcc}
\hline \multicolumn{1}{c}{ Normal } & 8 & $30,8 \%$ \\
\hline Hipertensi Ringan & 15 & $57,7 \%$ \\
\hline Hipertensi Sedang & 3 & $11,5 \%$ \\
\hline Hipertensi Berat & 0 & $0 \%$ \\
\hline Total & 26 & $100 \%$ \\
\hline $\begin{array}{l}\text { Dari tabel diatas menunjukkan bahwa } \\
\text { sebagian besar wanita menopause } \\
\text { pengguna daun }\end{array}$ & sambiloto yang \\
hipertensi ringan & berjumlah & 15 \\
responden (57,7\%). &
\end{tabular}

6. Distribusi Frekuensi Kriteria Hasil Penggunakan Daun Sambiloto

Tabel 6 Distribusi frekuensi responden berdasarkan kriteria hasil setelah menggunakan daun sambiloto untuk menurunkan hipertensi pada wanita menopause

\begin{tabular}{ccccc}
\hline $\begin{array}{c}\text { Kriteria } \\
\text { hasil }\end{array}$ & $\begin{array}{c}\text { Sebelum } \\
\text { menggunakan }\end{array}$ & $\%$ & Setelah menggunakan & \% \\
\hline$>140 \mathrm{mmHg}$ & 0 & $0 \%$ & 8 & $30,8 \%$ \\
\hline $\begin{array}{c}140-159 \\
\mathrm{mmHg}\end{array}$ & 4 & $15,4 \%$ & 15 & $57,7 \%$ \\
\hline $\begin{array}{c}160-179 \\
\mathrm{mmHg}\end{array}$ & 10 & $38,5 \%$ & 3 & $11,5 \%$ \\
\hline $\begin{array}{c}180-209 \\
\mathrm{mmHg}\end{array}$ & 12 & $46,1 \%$ & 0 & $0 \%$ \\
\hline Total & 26 & $100 \%$ & 26 & $100 \%$ \\
\hline
\end{tabular}

Dari tabel diatas menunjukkan bahwa sebagian besar wanita menopause penderita hipertensi setelah menggunakan daun sambiloto, hipertensi menurun, Hi[pertensi berat menjadi $0 \%$, hipertensi sedang $11,5 \%$, hipertensi ringan $57,7 \%$ dan tekanan darah normal 30,8\%.

\section{PEMBAHASAN}

\section{Wanita Menopause Penderita Hipertensi Sebelum Menggunakan Daun Sambiloto}

Berdasarkan hasil penelitian karakteristik responden berdasarkan usia menopause, menunjukkan bahwa usia menopause 51-55 tahun sebanyak 16 responden $(61,5 \%)$ sedangkan usia menopause 45-50 tahun sebanyak 10 responden (38,5\%). Ternyata di Desa Wonoagung Timur Kecamatan Tirtoyudo Kabupaten Malang, menopause lebih banyak terjadi pada usia 50-55 tahun. Hal ini dikarenakan beberapa factor yang menyebabkan menopause seperti nutrisi, olahraga dan stres.

Berdasarkan hasil penelitian karakteristik responden menurut hipertensi , menunjukkan bahwa Hipertensi Ringan (140 - 159 mmHg) sebanyak 4 responden $(15,4 \%)$, sedangkan Hipertensi Sedang (160 - $179 \mathrm{mmHg})$ sebanyak 10 responden $(38,5 \%)$ dan Hipertensi Berat $(180$ - $209 \mathrm{mmHg})$ sebanyak 12 responden (46,1\%). Ternyata di Desa Wonoagung Timur Kecamatan Tirtoyudo Kabupaten Malang Hipertensi Berat paling tinggi.Hal ini dikarenakan masih kurang perdulinya masyarakat tentang bahayanya hipertensi (Lestary, 2010) 
Wanita menopause penderita hipertensi di desa Wonoagung Timur Kecamatan Tirtoyudo Kabupaten Malang sebanyak 34 responden.Ketika wanita memasuki masa menopause perhatian terhadap keseimbangan tubuhnya mulai menurun. Dari hasil wawancara pada responden di desa inj, sebagian besar hipertensi disebabkan oleh factor keturunan dan kelelahan selain itu juga factor stress.

\section{Wanita Menopause Penderita Hipertensi Setelah Menggunakan Daun Sambiloto}

Berdasarkan hasil penelitian karakteristik responden menurut pengguna daun sambiloto, menunjukkan bahwa wanita menopause penderita hipertensi pengguna daun sambiloto terdapat 26 responden $(76,5 \%)$ dan 8 responden $(23,5 \%)$ bukan pengguna daun sambiloto. Ternyata di Desa Wonoagung Timur Kecamatan Tirtoyudo Kabupaten Malang, pengguna daun sambiloto sebagai obat lebih tinggi.Hal ini dikarenakan daun sambiloto dapat didapatkan dengan mudah, tidak ada efek samping, murah dan dapat dihentikan pemakaiannya.(Anonim 2006)

Berdasarkan hasil penelitian karakteristik responden menurut cara mengkonsumsi daun sambiloto, menunjukkan bahwa cara mengkonsumsi dengan cara merebus terdapat 10 responden $(38,5 \%)$ dan 16 responden $(61,5$ $\%)$ menggunakan cara menyeduh daun sambiloto. Ternyata di Desa Wonoagung Timur Kecamatan Tirtoyudo Kabupaten Malang, penggunaan daun sambiloto lebih tinggi menggunakan cara menyeduh. Hal ini dikarenakan daun sambiloto sangat pahit karena mengandung andrographolide (Wijoyo 2009)

Berdasarkan hasil penelitian karakteristik responden menurut frekuensi penggunaan daun sambiloto, menunjukkan bahwa wanita menopause penderita hipertensi pengguna daun sambiloto terdapat 26 responden sebanyak $100 \%$ di Desa Wonoagung Timur Kecamatan Tirtoyudo Kabupaten Malang, menggunakan daun sambiloto sebagai obat jika merasa sakit. Hal ini dikarenakan daun sambiloto dapat menimbulkan rasa tidak enak pada lambung dan hilangnya nafsu makan (Atlas Tumbuhan Obat Indonesia/Dr. Setiawan Dalimartha/Hadi. 2007)

Berdasarkan hasil penelitian karakteristik responden menurut lama penggunaan daun sambiloto, menunjukkan bahwa wanita menopause penderita hipertensi pengguna daun sambiloto selama 1-2 tahun sebanyak 18 responden $(69,2 \%)$ sedangkan yang menggunakan selama $<1$ tahun sebanyak 8 responden $(30,3 \%)$ dan yang menggunakan selama $>2$ tahun sebanyak 0 responden (0 \%) di Desa Wonoagung Timur Kecamatan Tirtoyudo Kabupaten Malang, menggunakan daun sambiloto sebagai obat selama 1-2 tahun lebih tinggi. Hal ini dikarenakan daun sambiloto baru dikenal oleh masyarakat akan khasiatnya.

Berdasarkan hasil penelitian karakteristik responden berdasarkan tekanan darah setelah menggunakan daun sambiloto, menunjukkan bahwa Hipertensi Ringan (140 - 159 mmHg) sebanyak 15 responden (57,5\%), sedangkan Tekanan darah Normal $(<140 \quad \mathrm{mmHg})$ sebanyak 8 responden $(30,8 \%)$, Hipertensi Sedang (160 - $179 \mathrm{mmHg})$ sebanyak 3 responden $(11,5 \%)$ dan Hipertensi Berat (180 - $209 \mathrm{mmHg}$ ) sebanyak 0 responden $(0 \%)$. Ternyata wanita menopause penderita hipertensi di Desa Wonoagung Timur Kecamatan Tirtoyudo Kabupaten Malang setelah menggunakan daun sambiloto tingkat penderita hipertensi mengalami penurunan.Hal ini dikarenakan dalam daun sambiloto terkandung kalium yang berguna untuk mengeluarkan air dan garam guna mengatasi hipertensi (Wijoyo, 2009) 
Hasil penelitian menunjukan bahwa mayoritas 26 responden $(76,5 \%)$ wanita menopause yang menggunakan daun sambiloto untuk menurunkan hipertensi, yang tidak menggunakan daun sambiloto 8 responden (23,5\%). Dari 26 responden wanita menopause yang menggunakan daun sambiloto untuk menurunkan hipertensi mendapatkan hasil $100 \%$ responden mengalami penurunan tekanan darah tinggi. Pencapaian hasil penggunaan daun sambiloto untuk menurunkan hipertensi pada wanita menopause di desa Wonoagung Timur Kecamatan Tirtoyudo Kabupaten Malang dapat dilihat melalui D/S, bisa dikatakan daun sambiloto termasuk antihipertensi apabila daun sambiloto dapat menurunkan hipertensi dalam 24 jam (Boedi Soesetyo, 2009).

\section{KESIMPULAN}

1. Penggunaandaunsambilotountukmen urunkanhipertensipadawanita menopause cukuptinggiyaitu $76,5 \%$ di DesaWonoagungTimur,

KecamatanTirtoyudo, Kabupaten Malang

2. Sebelummenggunakandaunsambiloto, angkahipertensipadawanita menopause di DesaWonoagungTimur, KecamatanTirtoyudo, Kabupaten Malang cukuptinggiyaitu 46,1\% wanita menopause menderitahipertensiberat.

3. Setelahmenggunakandaunsambiloto, angkahipertensipadawanita menopause di DesaWonoagungTimur, KecamatanTirtoyudo, Kabupaten Malang mengalamipenurunan, hipertensiberatmenjadi $\quad 0 \%$, sedangkanhipertensisedangmenjadi

$11,5 \%$, hipertensiringan $\quad 57,7 \%$ dantekanandarah normal menjadi $30,8 \%$

\section{DAFTAR PUSTAKA}

Anonim (2008). Penyakit Darah Tinggi (Hipertensi). Januari 2014

Arikunto (1998). Prosedur Penelitian. Jakarta, Rineka Cipta.

Emma, Nyoman (2008). Agar Tetap Sehat, Cantik, dan Bahagia di Masa Menopause. Jakarta: Gramedia.

Hembing Wijayakusuma, Prof.H.M (2007). Mencegah dan Mengatasi Hipertensi Secara Alamiah 05 Agustus 2014.

Januar, Ahmad (2007). Pemberdayaan Wanita dalam Bidang Kesehatan. Yogyakarta, Yayasan Essentia Medika.

Lestari, Dwi (2010). Seluk Beluk Menopause. Penerbit: Garailmu. Jogjakarta. 2010.

Notoatmodjo, Soekidjo (2008). Metodologi Penelitian Kesehatan. Jakarta, Rineka Cipta.

Padmiarso M. Wijoyo, Ir (2009). Ramuan herbal Anti Hipertensi. Seri pertama. Penerbit: Pustaka Agro Indonesia. Jakarta. 2012.

Padmiarso M. Wijoyo, Ir (2009). Sehat dengan Tanaman Obat. Seri keempat. Penerbit:Bee Media Indonesia. Jakarta. 2009.

Setiawan Dalimartha, dr (2008). Atlas Tumbuhan Obat Indonesia, Jilid 5 (Jakarta:Pustaka Bunda, 2008)

Wiramiharja (2010). Pengantar Psikologi Klinis. Bandung: PT. Refika Aditama. 